Vidya Wertta Volume 3 Nomor 2 Tahun 2020

p-ISSN 0852-7776-e-ISSN 2655-7282

https://ejournal.unhi.ac.id/index.php/vidyawertta

\title{
KEBIJAKAN HUMANIS PEMERINTAH DESA DALUNG TERHADAP MASYARAKAT LANJUT USIA
}

\author{
I Gede Jaya Kumara, I Putu Nuratama \\ jayakumara@unhi.ac.id \\ Universitas Hindu Indonesia Denpasar
}

\begin{abstract}
ABSTRAK
Sebagai daerah pariwisata, Kecamatan Kuta Utara, terdapat masyarakat yang tergolong masyarakat rentan serta perlu adanya perhatian khusus, yakni masyarakat lanjut usia. Masyarakat lanjut usia di usia mereka bukannya tidak dapat melakukan apa-apa, justru mereka dapat diberdayakan untuk meningkatkan kualitas hidup mereka. Maka pemberdayaan masyarakat lanjut usia salah satunya dengan menggunakan dana yang bersumber dari APBDes perlu untuk diketahui dan dikaji dengan penelitian. Khususnya di Desa Dalung perlu untuk dikaji penggunaan APBDes sebagai bagian kebijakan pemerintah yang berdasarkan atas nilai-nilai kemanusiaan kepada masyarakat lanjut usia. Maka relevan untuk diangkat judul penelitian yang dilakukan yakni "Kebijakan Humanis Pemerintah Desa Dalung Terhadap Masyarakat Lanjut Usia”. Pendekatan dilakukan dengan kajian humanisme, termasuk jenis penelitian kualitiatif, kemudian disajikan dengan narasi deskriptif. Simpulan penelitian menunjukan kebijakan humanis pemerintah ditunjukkan dengan adanya produk hukum yang pro terhadap masyarakat lanjut usia termasuk dengan pemberian anggaran khusus bagi masyarakat lanjut usia.
\end{abstract}

Kata Kunci: Kebijakan, Humanis, Masyarakat Lanjut Usia 


\section{ABSTRACT}

As a tourism area, North Kuta District, there are people who are classified as vulnerable communities and need special attention, namely the elderly. Older people at their age are not unable to do anything, they can be empowered to improve their quality of life. So the empowerment of the elderly, one of which is by using funds sourced from the APBDes, needs to be known and studied with research. Especially in Dalung Village, it is necessary to study the use of APBDes as part of government policy based on human values for the elderly. So it is relevant to be appointed the title of the research carried out, namely "Humanist Policy of the Village Government of Dalung Towards the Elderly Community". The approach is carried out by studying humanism, including the type of qualitative research, then presented with a descriptive narrative. The conclusion of the research shows that the government's humanist policy is shown by the existence of legal products that are pro to the elderly, including the provision of a special budget for the elderly.

Keywords: Policy, Humanist, Elderly Society

\section{PENDAHULUAN}

Saat ini Indonesia Negara yang menganut otonomi daerah, terdapat hubungan pusat dan daerah serta desa (Simandjuntak, 2016). Salah satu bentuk otonomi yang diberikan pemerintah pusat kepada daerah adalah dalam hal mengelola dan dana desa yang bersumber dari APBN dan kemudian menjadi APBDes di desa setelah digabung dengan pendapatan asli daerah. Tak terkecuali di desa yang ada di wilayah Kecamatan Kuta Utara. Dimana Kecamatan Kuta Utara terdiri dari 3 (tiga) desa, yakni desa Canggu, Desa Dalung, dan Desa Tibubeneng. Dana Desa yang dimiliki masing-masing desa tersebut pada tahun 2018 antara lain: Desa Canggu berjumlah Rp. 766.814.000,00, Desa Dalung berjumlah Rp. 910.710.000,00 dan Desa Tibubeneng berjumlah Rp. 832.401.000,00. Dana Desa tersebut digunakan untuk pemberdayaan masyarakat sekitar. Dengan jumlah penduduk Lansia di Kuta Utara berjumlah 3.300 Jiwa Laki-Laki dan 3.670 Jiwa Perempuan dari total penduduk 71.648 Jiwa. Dari komposisi penduduk di Kecamatan Kuta Utara, terdapat masyarakat yang tergolong masyarakat rentan serta perlu adanya perhatian khusus, yakni kaum lanjut usia, mereka dapat diberdayakan untuk meningkatkan kualitas hidup mereka. Sehingga masyarakat lanjut usia meningkat kesejahteraannya sebagai satu dari tujuan adanya dana desa (Yudianto, 2018: 2). Bantuan Alokasi Dana Desa yang diberikan oleh Pemerintah Kabupaten Badung merupakan pendorong pertumbuhan dan pembangunan di Desa. Sehingga Desa bisa menjadi desa yang 
mandiri dan secara terus menerus dapat meningkatkan pelayanan dan kesejahteraan masyarakatnya (Ummi, dkk: 2017: 2). Termasuk didalamnya kesejahteraan masyarakat lanjut usia, sehingga kebijakan tersebut digolongkan kebijakan yang humanis. Maka relevan untuk diangkat judul penelitian yang akan dilakukan yakni "Kebijakan Humanis Pemerintah Desa Dalung Terhadap Masyarakat Lanjut Usia". Penelitian ini menggunakan metode penelitian kualitatif, dengan teknik pengumpulan data lapangan di lokasi penelitian yakni Desa Dalung dan serta data tekstual kemudian dianalisis dan dinarasikan secara deskriptif untuk dilanjutkan dengan penarikan kesimpulan.

\section{PEMBAHASAN}

\subsection{Alokasi APBDes Dalung dan Kegiatan Masyarakat Lanjut Usia}

Hasil analisa terhadap kuisioner menunjukan terkait dengan persepsi responden terhadap pengetahuan terhadap besaran dan alokasi penggunaan APBDes Dalung khususnya yang digunakan untuk masyarakat lanjut usia, sebanyak 17 (tujuh belas) responden menjawab mengetahui adanya alokasi APBDes Dalung yang digunakan untuk kegiatan masyarakat lanjut usia. Ini artinya, bahwa pengelolaan APBDes Dalung, khususnya alokasi untuk masyarakat lanjyt usia dikategorikan transparan dan akuntabel. Ini sangat penting untuk dikaji mengingat akuntabilitas pengelolaan dana alokasi berjalan dengan baik jika transparansi pengelolaan dana alokasi desa berjalan trasparan hal ini terjadi jika karena adanya informasi yang mudah diakses serta komunikasi yang baik oleh perangkat desa sehingga pengengelolaan dana alokasi desa dianggap transparan (Nahruddin, 2014).

Adanya alokasi APBDes Dalung untuk pemberdayaan dan kegiatan masyarakat lanjut usia memberikan manfaat bagi masyarakat lanjut usia. Ini ditunjukkan dengan mayoritas responden menjawab bahwa APBDes Dalung memberikan dampak yang positif bagi masyarakat lanjut usia sebanyak 17 (tujuh belas) responden. Adanya manfaat yang dirasakan bagi masyarakat lanjut usia maka, kebijakan pemerintah Desa Dalung digolongkan ke dalam kebijakan yang responsif (Rusli, 2013), artinya kebijakan yang berasal dari kebutuhan masyarakat lanjut usia. Kebijakan yang responsif atas dasar kebutuhan masyarakat lanjut usia adalah kebijakan yang efektif karena memiliki manfaat bagi masyarakat (Dewi \& Adi, 2019).

Alokasi APBDes Dalung terhadap kegiatan masyarakat lanjut usia, mayoritas responden sebanyak 17 responden menyatakan bahwa besaran APBDes Dalung besarannya cukup untuk kegiatan pemberdayaan masyarakat lanjut usia. Terkait pemberdayaan masyarakat di desa sangat tergantung terhadap kesediaan dana, salah satunya yang bersumber dari APBDes (Karimah et al., 2014). Ketersediaan dana merupakan acuan awal untuk merencanakan suatu kegiatan, termasuk pula 
ketersediaan dana dalam APBDes Dalung menjadi pedoman awal untuk merencanakan dan melaksanakan kegiatan yang terkait dengan masyarakat lanjut usia di Desa Dalung. Mayoritas responden 15 rasponden menyatakan bahwa jika tidak ada APBDes Dalung yang khusus dialokasikan untuk masyarakat lanjut usia maka masyarakat lanjut usia tidak ada kegiatan.

Masyarakat lanjut usia sangat tergantung kepada APBDes Dalung dalam melaksanakan berbagai kegiatan, mengingat jumlah masyarakat lanjut usia di Desa Dalung cukup banyak, dapat dilihat pada tabel dibawah ini.

\section{Tabel 1}

Jumlah Lanjut Usia di Desa Dalung

\begin{tabular}{|l|l|l|l|l|l|}
\hline NO & BANJAR & \multicolumn{4}{|l|}{ JUMLAH LANSIA } \\
\cline { 4 - 6 } & & KK & $\begin{array}{l}\mathbf{6 0 - 6 5} \\
\text { Thn }\end{array}$ & $\mathbf{6 6 - 7 0}$ Thn & $\mathbf{7 1}$ Thn \\
\hline 1 & Tegal Jaya & 336 & 62 & 36 & 67 \\
\hline 2 & Celuk & 121 & 33 & 20 & 29 \\
\hline 3 & Pendem & 254 & 47 & 31 & 55 \\
\hline 4 & Gaji & 156 & 33 & 16 & 34 \\
\hline 5 & Untal-Untal & 244 & 47 & 33 & 52 \\
\hline 6 & Kwanji & 498 & 71 & 44 & 33 \\
\hline 7 & Tegeh & 199 & 43 & 24 & 44 \\
\hline 8 & Kaja & 259 & 40 & 14 & 25 \\
\hline 9 & Cepaka & 330 & 27 & 10 & 24 \\
\hline 10 & Lebak & 98 & 15 & 14 & 25 \\
\hline 11 & Kung & 162 & 19 & 12 & 21 \\
\hline 12 & Padang Bali & 138 & 32 & 18 & 31 \\
\hline 13 & Dukuh & 469 & 170 & 125 & 92 \\
\hline 14 & Pangilian & 357 & 35 & 19 & 16 \\
\hline 15 & Pegending & 340 & 36 & 25 & 29 \\
\hline 16 & Tuka & 250 & 42 & 31 & 56 \\
\hline 17 & Lingga Bumi & 248 & 42 & 12 & 14 \\
\hline 18 & Camas Kalih & 29 & 23 & 10 & 3 \\
\hline 19 & Camas Kangin & 195 & 27 & 11 & 3 \\
\hline 20 & Binus Kauh & 298 & 43 & 11 & 8 \\
\hline 21 & Binus Kangin & 196 & 22 & 5 & 2 \\
\hline 22 & Tegal Luwih & 192 & 33 & 8 & 6 \\
\hline 23 & Taman Tirta & 41 & 11 & 2 & 1 \\
\hline & & $5.590 /$ & 953 & 531 & 670 \\
\hline & & 23.112 Jiwa & & & \\
\hline & & & & \\
\hline
\end{tabular}


Berdasarkan tabel diatas jumlah total masyarakat lanjut usia di Desa Dalung sebanyak 2.154 jiwa. Masyarakat lanjut usia terbanyak tercatat di Banjar Dukuh dengan total 387 Jiwa masyarakat lanjut usia atau 17,9\%, selanjutnya disusul Banjar Tegal Jaya dengan jumlah masyarakat lanjut usia sebanyak 165 jiwa atau 7,6\% dan di urutan ketiga Banjar Kwanji dengan jumlah masyarakat lanjut usia sebanyak 148 jiwa atau $6,8 \%$.

Keberhasilan dari kegiatan masyarakat lanjut usia yang didanai oleh APBDes Dalung sangat tergantung dengann keaktifan masyarakat lanjut usia yang mengikuti kegiatan yang telah diprogramkan oleh pemerintah Desa Dalung. Partisipasi masyarakat dan sinergi dengan pemerintah desa menjadi salah satu kunci suksesnya program-program yang direncanakan pemerintah desa (Tumbel, 2017). Saat ini setidaknya telah ada 25\% dari jumlah Banjar/Lingkungan di Desa Dalung yang memiliki organisasi khusus lanjut usia. Ini artinya, jika dilihat dari tingkat keberadaan organisasi khusus masyarakat lanjut usia di Desa Dalung masih tergolong minim, walaupun begitu secara individu keaktifan masyarakat lanjut usia untuk mengikuti kegiatan yang dananya bersumber dari APBDes Dalung cukup aktif.

Selain keaktifan dari masyarakat lanjut usia itu sendiri untuk mengikuti kegiatan yang dananya bersumber dari APBDes Dalung, terdapat juga peran dari aparat pemerintah Desa Dalung. Mayoritas responden menyatakan bahwa terdapat peran yang baik dari aparat Banjar/Lingkungan sampai pada aparat Desa dalam pelaksanaan kegiatan masyarakat lanjut usia yang bersumber dari APBDes Dalung. Peran pemerintah Desa Dalung melalui aparat desa dalam pengelolaan APBDes diperlukan peran dan tanggung jawab pemerintah desa (Fajri et al., 2015), khususnya dalam hal perencanaan dan pelaksanaan kegiatan untuk masyarakat lanjut usia di Desa Dalung.

Alasan masyarakat lanjut usia perlu diperhatikan, terdapat beberapa alasan yang menjadi alasan yang kuat berdasarkan pendapat responden, antara lain: kegiatan yang melibatkan masyarakat lanjut usia dilakukan untuk menjaga harapan hidup, untuk memberikan ruang interaksi dengan sesama masyarakat lanjut usia, meningkatkan kesehatan jasmani dan rohani dan adanya kebijakan dari pemerintah yang memberikan perhatian khusus kepada masyarakat lanjut usia.

\subsection{Kebijakan Humanis dan Responsif Pemerintah Desa Dalung Terhadap Masyarakat Lanjut Usia}

Ternyata tidak hanya melalui alokasi APBDes Dalung dalam bentuk kegiatan untuk masyarakat lanjut usia di Desa Dalung, namun juga secara khusus, di lokasi penelitian Desa Dalung, Kecamatan Kuta Utara, Kabupaten Badung, terdapat peran 
pemerintah Kabupaten Badung untuk memberikan bantuan dana kepada masyarakat lanjut usia, ditunjukkan dengan dikeluarkannya Peraturan Bupati Badung Nomor 48 Tahun 2019 Tentang Perlindungan Dan Rehabilitasi Sosial Lanjut Usia. Peraturan Bupati ini memberikan perlindungan dalam bentuk perlindungan hukum dan upaya rehabilitasi untuk mengembalikan fungsi sosial dari masyarakat lanjut usia itu sendiri. Pemerintah sangat berperan dan sangat diharapkan perannya dalam mendukung keberadaan lanjut usia di Desa Dalung. Responden menyatakan bahwa faktor yang dominan dalam kegiatan masyarakat lanjut usia yang menggunakan APBDes adalah faktor aparat Banjar dan/atau Desa serta faktor keaktifan masyarakat lanjut usia itu sendiri dalam mengikuti kegiatan, serta faktor ada/ tidak alokasi APBDes Dalung yang khusus untuk pemberdayaan masyarakat lanjut usia.

Pemerintah Kabupaten Badung melalui Peraturan Bupati Badung Nomor 48 Tahun 2019 diterbitkan dengan dasar pertimbangan untuk mewujudkan kehidupan yang layak dan bermanfaat (artinya masyarakat lanjut usia diharapkan mendapatkan kehidupan yang layak dan bermanfaat dengan dikeluarkannya Peraturan Bupati tersebut). serta untuk pemenuhan kebutuhan dasar minimal dan pelaksanaan fungsi sosial secara wajar demi tercapainya kesejahteraan sosial bagi lanjut usia yang telah melewati usia harapan hidup. Serta untuk memberikan penghormatan dan penghargaan kepada lanjut usia di Kabupaten Badung, berupa bantuan perlindungan dan rehabilitasi sosial yang dilakukan secara terarah, terencana dan berkelanjutan. Dengan tujuan untuk memulihkan dan mengembangkan kemampuan lanjut usia yang mengalami disfungsi sosial sehingga dapat melaksanakan fungsi sosialnya secara wajar; dan untuk mencegah dan menangani resiko dari guncangan dan kerentanan sosial lanjut usia.

Perlindungan dan rehabilitasi sosial masyarakat lanjut usia dilaksanakan dalam bentuk pemberian bantuan berupa uang yang diperuntukan bagi lanjut usia yang tidak potensial paling rendah usia 75 (tujuh puluh lima) tahun; atau bedridden yang telah mencapai usia 60 (enam puluh) tahun keatas. Bantuan berupa uang diberikan sebesar Rp. 1.000.000,00 (satu juta rupiah) setiap bulan sesuai dengan kemampuan keuangan Daerah. Sedangkan, bagi Lanjut Usia yang sedang menerima pensiunan/santunan dari Pemerintah/Lembaga Sosial, serta yang menjadi binaan dan tanggung jawab Panti Sosial Tresna Werdha/Panti Sosial, tidak berhak untuk menerima Bantuan Perlindungan dan Rehabilitasi Sosial Lanjut Usia.

Adapun persyaratan administrasi Calon Penerima Perlindungan dan Rehabilitasi Sosial Lanjut Usia terdiri atas:
a. fotocopy Kartu Tanda Penduduk Elektronik (KTP-el) Daerah/surat keterangan perekaman Kartu Tanda
b. Penduduk Elektronik (KTP-el) dari perangkat daerah yang melaksanakan urusan pemerintahan bidangkependudukan dan pencatatan sipil;
c. fotocopy Kartu Keluarga (KK); 
d. fotocopy buku tabungan Bank Pembangunan Daerah (BPD) Bali atas nama Lanjut Usia;

e. surat keterangan dari Perbekel/Lurah setempat yang menerangkan bahwa Lanjut Usia yang bersangkutan sudah berdomisili di Daerah paling singkat 5 (lima)tahun;

f. pakta integritas yang di tandatangani pihak keluarga;

g. bagi Lanjut Usia Bedridden di buktikan dengan surat keterangan diagnosa dari tenaga medis; dan

h. bagi Lanjut Usia Bedridden melampirkan surat kuasa, yang diketahui oleh Perbekel/Lurah setempat;

Pencairan bantuan Perlindungan Dan Rehabilitasi Sosial Lanjut Usia dilaksanakan secara non tunai sesuai dengan ketentuan peraturan perundangundangan. Pencairan Bantuan Perlindungan dan rehabilitasi Sosial Lanjut usia dilaksanakan setiap 3 (tiga) bulan. Pembiayaan penyelenggaraan pemberian bantuan Perlindungan dan Rehabilitasi Sosial Lanjut Usia dibebankan pada Anggaran Pendapatan dan Belanja Daerah.

Pemerintah Desa Dalung memberikan alokasi khusus lanjut usia. Pada Tahun 2018 /2019 Setidaknya ada penggunaan dan adesa yang ditujukan untuk kegiatan masyarakat lanjut usia di Desa Dalung. Dapat dilihat pada tabel dibawah ini

\section{Tabel 1}

Alokasi Dana Desa Dalung untuk Lansia Tahun 2018

\begin{tabular}{|l|l|l|}
\hline No & Uraian Penggunaan Dana & Anggaran \\
\hline 1 & Snack untuk Tim Pembinan Kegiatan Lansia & Rp. 800.000 \\
\hline 2 & $\begin{array}{l}\text { Snack Pembukaan dan Penutupan Posyandu } \\
\text { Paripurna }\end{array}$ & Rp. 3.000.000 \\
\hline 3 & $\begin{array}{l}\text { Nasi Pembukaan dan Penutupan Posyandu } \\
\text { Paripurna }\end{array}$ & Rp. 7.500.000 \\
\hline 4 & $\begin{array}{l}\text { Pemberian Makanan Tambahan bagi Lanjut } \\
\text { Usia Selama Pembukaan dan Penutupan } \\
\text { Posyandu Paripurna }\end{array}$ & Rp. 20.000.000 \\
\hline 5 & $\begin{array}{l}\text { Honor Petugas Kesehatan dan Pelatih Senam } \\
\text { Lansia }\end{array}$ & Rp. 19.000.000 \\
\hline 6 & Belanja Dekorasi & Rp. 600.000 \\
\hline & Total & Rp. 50.900.000 \\
\hline
\end{tabular}

Kebijakan pemerintah Desa Dalung yang mengalokasikan dana untuk kegiatan masyarakat lanjut usia melalui APBDes Dalung dikategorikan sebagai kebijakan yang humanis. Kebijakan humanis merupakan suatu kebijakan yang memanusiakan manusia. Artinya, kebijakan humanis pemerintah dicerminkan dengan kebijakan 
yang memberdayakan masyarakat lanjut usia sebagai pengguna kebijakan (Prasodjo, 2017). Kebijakan humanis pemerintah desa Dalung tersebut sesuai dengan nilsi-nilai dalam Pancasila, khususnya nilai sila ke 2 (dua) yakni, nilai kemanusiaan yang adil dan beradab. Kebijakan pemerintah Desa Dalung memberikan ruang kreativitas dan alokasi dana melalui APBDes telah mencerninkan nilai kemanusiaan yang adil, dalam artian adil disini adalah semua golongan usia tanpa terkecuali masyakarakat lanjut usia yang menjunjung tinggi nilai-nilai keberadaban. Implementasi nilai kemanusiaan dalam kebijakan pemerintah Desa Dalung tentunya juga dijiwai/ disinari dengan nilai-nilai Ketuhanan, dimana semua manusia memiliki kedudukan yang sama. Dengan dijunjungnya nilai-nilai kemanusiaan yang disinari nilai Ketuhanan maka, tujuan untuk mencapai persatuan Indonesia yang adil dan sejahtera atas dasar nilai kebersamaan akan tercapai.

Nilai-nilai humanis yang terkandung pada nilai sila kemanusiaan yang adil dan beradab pada era globalisasi mendapatkan ancaman dari berkembangnya paham liberal dan individualistik yang digerakan atas dasar kebebasan dan persaingan. Tentunya ini bertolak belakang dengan nilai humanis yang menitikberatkan pada adanya komunikasi dan interaksi sosial antar sesama manusia untuk mencapai tujuan bersama. Interaksi sosial merupakan hubungan sosial yang saling mempengaruhi antar individu yang terjadi di masyarakat yang berlangsung sepanjang hidupnya.

Interaksi sosial dapat berdampak positif terhadap kualitas hidup karena dengan adanya interaksi sosial maka lansia tidak merasa kesepian, oleh sebab itu interaksi sosial harus tetap dipertahankan dan dikembangkan pada kelompok lansia. Lanjut usia yang dapat terus menjalin interaksi sosial dengan baik adalah lansia yang dapat mempertahankan status sosialnya berdasarkan kemampuan bersosialisasi (Noorkasiani, 2009). Adanya perubahan kualitas hidup yang dialami oleh lansia biasanya cenderung mengarah ke arah yang kurang baik. Biasanya hal tersebut berhubungan dengan lingkungan sosial ekonomi lansia seperti berhenti bekerja karena pensiun, kehilangan anggota keluarga yang dicintai dan teman, dan ketergantungan kebutuhan hidup serta adanya penurunan kondisi fisik yang disebabkan oleh faktor usia.

Sebagai comtoh interaksi sosial yang telah dilakukan oleh penduduk lanjut usia di Desa Dalung, sebagai berikut. 


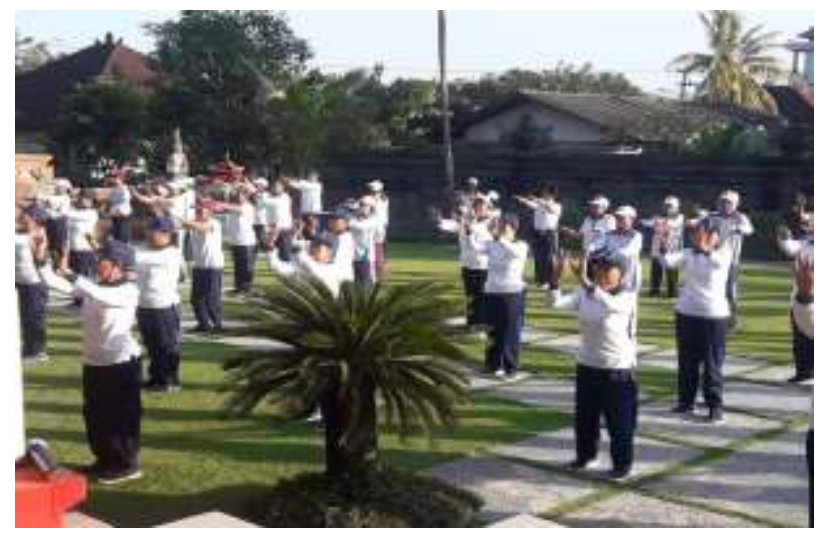

Gambar 1

Lanjut Usia Melakukan Senam Bersama

Kegiatan senam bersama yang dilakukan masyarakat lanjut usia di Desa Dalung yang dibiayai oleh APBDes Dalung memberikan beberapa manfaat, antara lain: masyarakat lanjut usia mendapatkan kesehatan jasmani yang dihasilkan dari kegiatan olahraga yang sesuai dengan kebutuhan lanjut usia, masyarakat lanjut usia dengan melakukan kegiatan senam bersama dapat berkomunikasi dan berinterkasi antar sesama masyarakat lanjut usia sehingga kehidupan sosial mereka tetap terjaga serta manfaat lainnya pulihnya kesehatan mental para lanjut usia karena melakukan aktifitas kembali diluar rumah masing-masing. Kegiatan lainnya yang memupuk nilai-nilai komunikasi, kebersamaan dan interkasi serta nilai kesenian para lanjut usia dapat dilihat pada gambar di bawah ini.

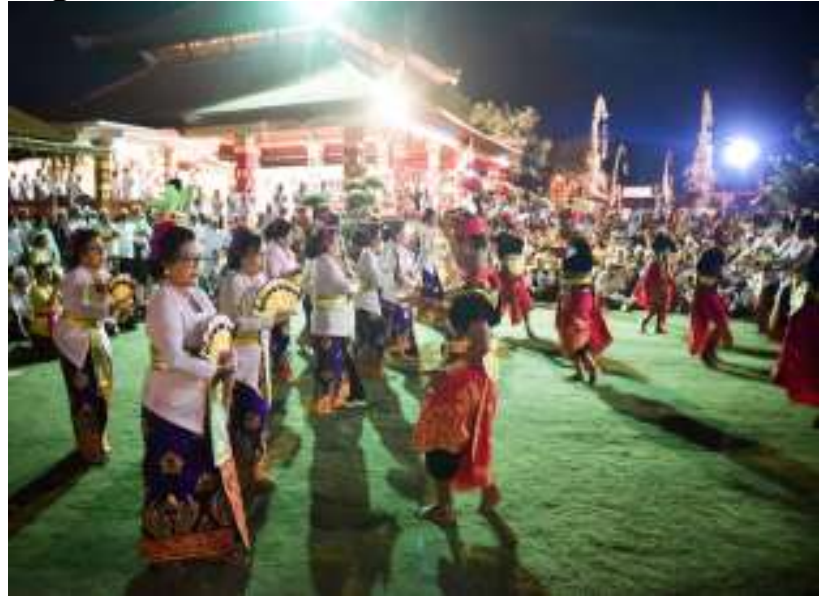

Gambar 2

Lanjut Usia Mengikuti Perlombaan Tarian Janger

Kegiatan masyarakat lanjut usia lainnya yang dilakukan dengan adanya bantuan APBDes Dalung adalah melakukan kegiatan perlombaan mejejahitan (merangkai seni janur). Kegiatan lomba mejejahitan memberikan beberapa manfaat bagi masyarakat lanjut usia di Desa Dalungm antara lain: menumbuhkan komunikasi 
dan berinteraksi untuk mencapai satu tujuan yang sama, meningkatkan nilai kebersamaan dan memulihkan aktifitas kesenian yang dimiliki para lanjut usia. Sebagai contoh dapat dilihat pada ilustrasi gambar di bawah ini.

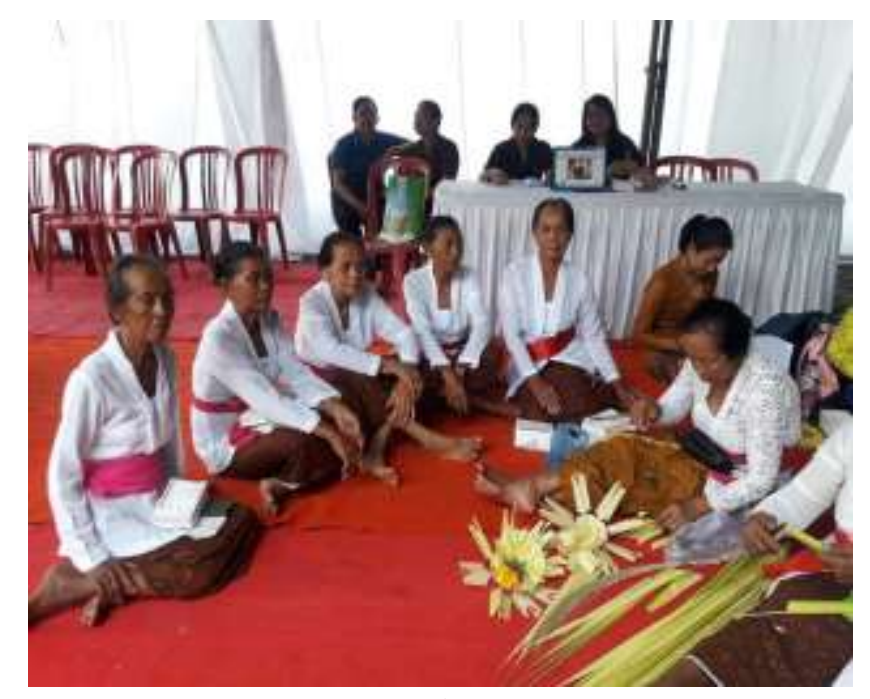

Gambar 3

Lanjut usia melakukan kegiatan mejejahitan

Peran kebijakan humanis pemerintah tersebut harus didukung pula oleh pihak keluarga. Masyarakat lanjut usia bukanlah beban keluarga. Merubah mindset lansia sebagai aset membutuhkan komitmen dan dukungan semua pihak termasuk keluarga dan kerabat lanjut usia. Artinya, tugas untuk memperhatikan masyarakat lanjut usia tidak hanya ada di Pemerintah, melainkan dimulai dari susunan terkecil masyarakat yakni keluarga. Warga lanjut usia harus disediakan ruang publik deliberatif dalam pembangunan, pelayanan sosial dan mental spiritual dalam menghadapi akhir hidupnya (Perguna, 2016).

Sehingga masyarakat lanjut usia tetap hidup bahagia. Terdapat 14 faktor yang mempengaruhi kebahagiaan lanjut usia (penghasilan; usia; agama; budaya; bersyukur kepada Tuhan; aktivitas fisik; hubungan sosial; memaafkan; kualitas hidup; silaturahmi; sehat; menikah; berhubungan baik dengan anak, cucu, dan menantu; serta berhubungan baik dengan saudara) dan terdapat 13 afek yang mempengaruhi kebahagiaan lanjut usia (merasa senang, sabar, suasana tenang, optimis, ayem tenteram, trenyuh, perhatian, bersemangat, tidak dendam, santai, sopan, senang menolong/memberi, dan tidak takut meninggal/pasrah kepada takdir diusia tua) (Diponegoro \& Mulyono, 2015).

Selain itu, kesehatan spiritual masyarakat lanjut usia perlu dibangun dengan baik membantu lansia menghadapi kenyataan, berpartisipasi dalam hidup, merasa memiliki harga diri dan menerima kematian sebagai sesuatu yang tidak dapat dihindari (Potter \& Perry, 2009). Faktor yang memengaruhi kesehatan spiritual 
seseorang adalah pertimbangan tahap perkembangan, keluarga, latar belakang etnik dan budaya, agama dan pengalaman hidup sebelumnya (Taylor, Lillis, LeMone P \& Lynn, 2011).

\section{PENUTUP}

\subsection{Simpulan}

Masyarakat lanjut usia di Desa Dalung telah mendapatkan perhatian dari pemerintah, baik pemerintah Desa Dalung melalui kegiatan bagi masyarakat lanjut usia yang di biayai APBDes Dalung, maupun melalui peran pemerintah Kabupaten Badung yang memberikan insentif bagi masyarakat lanjut usia berupa uang tunai yang diberikan setiap bulan. Kebijakan tersebut digolongkan kebijakan yang humanis kepada masyarakat lanjut usia di Desa Dalung. Peran aparat pemerintah sangat diperlukan dalam pemberdayaan masyarakat lanjut usia di Desa Dalung.

\subsection{Saran}

Adapun saran yang dapat disampaikan untuk efektifnya kebijakan Pemerintah Desa Dalung dalam pemberdayaan lanjut usia antara lain: dengan cara meningkatkan peran aparat desa/banjar/lingkungan di Desa Dalung, meningkatkan keefektifan anggota lanjut usia dalam kegiatan yang telah direncenakan, menyediakan beberapa fasilitas umum yang khusus untuk masyarakat lanjut usia dan dengan mencanangkan program Desa Dalung Desa Ramah Lanjut Usia.

\section{DAFTAR PUSTAKA}

Dewi, D. E., \& Adi, P. H. (2019). Transparansi, Akuntabilitas, Partisipasi Masyarakat Dalam Pengelolaan Keuangan Dana Desa (Studi Kasus Desa Candirejo Kecamatan Pringapus Kabupaten Semarang). Jurnal Ilmiah Edunomika. https://doi.org/10.29040/jie.v3i02.595

Diponegoro, A. M., \& Mulyono, M. (2015). Faktor-Faktor Psikologis yang Mempengaruhi Kebahagiaan pada Lanjut Usia Suku Jawa di Klaten. Psikopedagogia Jurnal Bimbingan Dan Konseling. https://doi.org/10.12928/psikopedagogia.v4i1.4476

Fajri, R., Setyowati, E., \& Siswidiyanto. (2015). Akuntabilitas Pemerintah Desa

Pada Pengelolaan Alokasi Dana Desa (Studi Pada Kantor Desa Ketindan, Kecamatan Lawang, Kabupaten Malang). Jurnal Administrasi Publik (JAP).

Karimah, F., Saleh, C., \& Wanusmawatie, I. (2014). Pengelolaan alokasi dana desa dalam pemberdayaan masyarakat (Studi pada Desa Deket Kulon Kecamatan Deket Kabupaten Lamongan). Jurnal Administrasi Publik.

Nahruddin, Z. (2014). Akuntabilitas Dan Transparansi Pengelolaan Dana Alokasi

Desa Di Desa Pao-Pao Kecamatan Tanete Rilau Kabupaten Barru. Otoritas : 
Jurnal Ilmu Pemerintahan. https://doi.org/10.26618/ojip.v4i2.95

Noorkasiani, T. S. 2009. Kesehatan Usia Lanjut dengan Pendekatan Asuhan Keperawatan. Jakarta: Salemba Medika

Perguna, L. A. (2016). Ruang Publik Katup Penyelamat Penduduk Lanjut Usia (Studi Gerontologi Sosial di Pondok Sepuh Payaman Magelang). Jurnal Sosiologi Pendidikan Humanis. https://doi.org/10.17977/um021v1i12016p047

Potter, P. A. dan Perry, A. G. 2005. Fundamental of Nursing: Consepts, Process, and Practice (4thediti)

Prasodjo, T. (2017). Paradigma Humanis dalam Pelayanan Publik. Jurnal Ilmiah Ilmu Administrasi Publik. https://doi.org/10.26858/jiap.v7i1.3438

Rusli, B. (2013). Kebijakan Publik: Membangun Pelayanan Publik yang Responsif. Kebijakan Publik.

Simandjuntak, R. (2016). Sistem Desentralisasi Dalam Negara Kesatuan Republik Indonesia Perspektif Yuridis Konstitusional. Journal de Jure. https://doi.org/10.18860/j-fsh.v7i1.3512

Tumbel, S. M. (2017). Partisipasi Masyarakat Dalam Pengelolaan Dana Desa Di Desa Tumaluntung Satu Kecamatan Tareran Kabupaten Minahasa Selatan. Jurnal Politico. 